\title{
Transnational Dialogues for sustainability research in early childhood education: A model for building capacity for ESD in universities?
}

Sherridan Emery

Faculty of Education

University of Tasmania

Tasmania, Australia

Email: sherridan.emery@utas.edu.au

Prof. Julie M. Davis

Faculty of Education, Early Childhood

Queensland University of Technology

Brisbane, Australia

Email: j.davis@qut.edu.au

Dr Barbara Maria Sageidet

Department of Arts and Education, Institute of Early Childhood Education

University of Stavanger

Stavanger, Norway

Email: barbara.sageidet@uis.no

Nicky Hirst

School of Education

Liverpool John Moores University

Liverpool, United Kingdom

Email: n.j.hirst@ljmu.ac.uk

Diane Boyd

School of Education

Liverpool John Moores University

Liverpool, United Kingdom

Email: d.j.boyd@1jmu.ac.uk

Jamison K. Browder

College of Education

University of South Carolina

Columbia, South Carolina United States of America

Email: jkbrowder@hotmail.com

\begin{abstract}
:
Early childhood education (ECE) within tertiary education has proactively responded to calls to realign preservice teacher education towards more sustainable futures, with Early Childhood Education for Sustainability (ECEfS) developing rapidly as a field of research and practice. An international multi-university initiative that has been a key impetus for ECEfS since 2010 is the Transnational Dialogues in Research in Early Childhood Education for Sustainability (TND). The TND is an international group of experienced and early career researchers that fosters collaborations between individuals and groups of researchers, universities and ECE practitioners. In particular, the group aims to build researcher capacity for instigating projects that activate sustainability learning in ECE.
\end{abstract}


This paper reports on three research projects emerging from the third TND and articulates strategies and processes for sustaining ongoing research dialogues in order to promulgate new fields of sustainability research through its collaborations. The authors believe that this kind of dialogic process offers other universities and disciplines a model for embedding sustainability into their processes and structures.

\section{Keywords:}

Transnational dialogues; Education for Sustainability; Early Childhood Education for Sustainability; ecological worldview; curriculum frameworks; teacher education; sustainability research

\section{Introduction}

The tertiary education sector has been relatively slow to respond to calls for the reorientation of education towards sustainability, despite being advocated for in numerous key international publications from, for example, the United Nations and the United Nations Educational, Scientific and Cultural Organization (UNESCO), and especially those emanating from the UN Decade of Education for Sustainable Development (DESD) (UNESCO 2005 - 2014). This absence is particularly notable within the field of early childhood education and care (ECEC) teacher education and research, despite the likelihood that young children will experience the most significant impacts of unsustainable societies (Davis \& Elliott 2014).

\section{The Transnational Dialogues in Early Childhood Education for Sustainability (TND in} ECEfS), an informal international network of ECEC teacher educators, researchers, and practitioners that developed through the impetus of the DESD, has had significant influence on the emergence of a new productive international research field in sustainability education, spawning new research directions, fostering international conversations about research, and delivering several research publications. This paper, produced collaboratively by researchers and academics engaged in the TND, outlines this initiative, and presents the TND as a model for other multi-university initiatives, with a main purpose of promoting collaborative and practice oriented international research that activates transformative sustainability learning

First, we present the development of the Transnational Dialogues and summarize significant new research growing out of the dialogues. Confident that the TND represents a useful model for the development of other sustainability fields in the tertiary education sector, we conceptualize the TND as an informal decentralized network and share lessons learned about its usefulness for sustaining an international network and community of practice. In revealing the processes, challenges and successes involved in advancing the TND, this paper encourages the formation of other new international collaborations in sustainability research.

\section{What is the TND in ECEfS?}

In 2010, an Australian researcher, Prof. Julie Davis, and Prof. Eva Johansson, a researcher from Norway, initiated the Transnational Dialogues in Early Childhood Education for Sustainability. Their intention was to organize a forum whereby international researchers could share multi-national, multi-cultural and multi-disciplinary perspectives and experiences 
with the overall goal of provoking interest and ideas for future collaborative research, publications, scholarly exchanges and mentoring. The research forum - organized without any external funding apart from basic investments from the host university to cover meals - was planned as a democratic, outcomes-oriented workshop with multiple opportunities for networking between participants. At the time, the field of ECEfS had a very small research base (Davis 2009), and it was decided the workshop should bring together researchers with an interest in ECEfS, even if they did not work directly in the area.

The inaugural TND took place in Stavanger, Norway, in August 2010, as a joint Queensland University of Technology (QUT) and University of Stavanger event. The meeting was held after the World Organization for Early Childhood Education (OMEP) Congress in Sweden, a conference primarily for practitioners, but with an emerging research focus. Fifteen researchers at various stages of their research careers were invited to attend the TND from Australia, New Zealand, Norway and Sweden. This first meeting initiated the TND's ongoing research agenda, which is to proactively investigate ways of knowing and understanding how young children are recognized as, and learn to be, active citizens for sustainability. The action outcomes from this first meeting included a number of ideas to drive collaborative research proposals and papers, a strong desire to continue networking within the ECEfS community, and a submission from participants to the deliberations that preceded the United Nations Rio +20 conference on sustainable development in 2012, which advocated for children's voices and their particular considerations to be integral to global decision-making about sustainability.

TND2 was held in Brisbane in July 2011, in tandem with the $6^{\text {th }}$ World Environmental Education Congress (WEEC), with additional participants from Korea, Japan, and Singapore offering broader international representation, and diverse social-geographical-cultural perspectives on research in ECEfS. Continuing with the focus on building research capacity in ECEfS, action outcomes included new research and writing collaborations, a number of international Visiting Scholar events, several joint research grant applications with international collaborators, and further refereed publications with international co-authors. The most significant output that included participants from both TND1 and TND2 was a research book edited by Davis and Elliott (2014), which has provided a platform for the further promotion of research in ECEfS, and has already been translated into Korean (Davis \& Elliott 2015). The 19 chapters from researchers from nine nations range across three themes: ethics and values, historical and sociocultural contexts, and curriculum and pedagogy.

The third TND returned to Stavanger (July 2015), ahead of the WEEC in Sweden. The increased number of participants and countries represented at this meeting demonstrated the growing interest in ECEfS amongst researchers and added further new perspectives and approaches to the expanding field of ECEfS research. In addition to participants who had attended one or both of the early TNDs, this meeting also included researchers from the United Kingdom, Canada and the United States. Arising from TND3 are five research subgroups, of which three of these collaborations are profiled in following sections of this paper.

In summary, TND has been a means for building international research capacity in a new area of education for sustainability research, but it is still in its infancy. We acknowledge, for example, that there are currently no voices from First Nations peoples or from Africa or Latin America in the TND and that the research perspectives and methodologies reflect those of the main participants. We do hope and anticipate, however, that these gaps will be addressed in the future and that the TND and other such collaborations will encourage the emergence of new voices and perspectives. Such diversity is vital if the field is to continue to grow, prosper and make an impact. 


\section{Research projects emerging from TND3}

Here we outline three of the collaborative international studies that are currently being investigated by TND3 researchers. Each project has been developed by those who expressed interest in the topic, and that emerged from a process of brainstorming begun on the second day of the workshop. Through further inclusive debate, discussion and negotiation, a large number of discrete topics were distilled into five 'researchable' themes or topics.

\subsection{Transnational case studies of children's webs of connectedness in ECEfS}

In this first study, the researchers have a wide range of research experience - from that of a full professor with limited publications in English, a doctoral candidate, and a practicing teacher with a strong interest in ECEfS research who recently commenced doctoral studies. Inoue (2014) asserts that early childhood educators who offer daily learning experiences that embed ecological concepts such as biodiversity, life cycles, and human-nature interdependency have the potential to foster an "ecological worldview" in young children, where interconnections between elements are paramount. She also asserts that understandings of ecological worldviews vary among educators and centers, regions and countries. This multiplicity of perspectives makes it difficult to generalize what teaching for an ecological worldview might look like in early childhood education. The researchers decided to employ case study design for the research with a focus on how features within local contexts influence educators' pedagogical practices and opportunities for children to develop ecological worldviews.

This research of young children's ecological worldviews has been conducted in three contexts: Australia, Japan, and the United States. Inoue, from Japan, has already researched the development of ecological worldviews in ECE with very young children (Inoue 2014), with this research then taken up by Emery (Australia) and Browder (USA) who in turn conducted cases in their own home countries. Here, these latter two case studies are briefly described.

\subsubsection{An Australian case study}

Conducted in Triabunna on the east coast of Tasmania in southern Australia, this case study explores webs of connectedness (or connections) at an early childhood education (ECE) center located near Great Oyster Bay, a region that is a breeding ground for fairy penguin colonies. As part of the center's ongoing learning program, young children have begun learning about the webs of connections between habitat change and the penguins.

The region's parks and wildlife services (PWS) invited a childcare centre in Triabunna to partner with them in a penguin breeding program in which children from the center built breeding boxes for the penguin colony on nearby Little Christmas Island. As a result of changing seasonal conditions, the habitat on Little Christmas Island has also changed, leading to a decline in the penguin colony and a slowing of their breeding, due to a lack of food for the penguins, as well as ongoing predation. PWS presented this problem to the children at the center and discussed with them how the breeding boxes represent a human-designed adaptation to climate change which supports the survival of the penguin population in this area. Using design plans provided by PWS, the children worked together with the groundsman from the childcare centre to build six timber breeding boxes designed to provide 
a safe habitat for nesting penguins that the PWS then installed on the small rocky island. The children's connection with the life cycle of the fairy penguins was sustained through ongoing reporting on the progress of the island's penguin population by PWS staff and through ongoing conversations with the children.

By explicitly introducing concepts of interdependencies between humans and nature into the learning program (Inoue 2014), this Australian case study illustrates that early childhood learning can be oriented towards environmental awareness and sustainability. Further, such learning supports the national curriculum outcomes of the Early Years Learning Framework for Australia (Department of Education Employment and Workplace Relations (DEEWR) 2009), in particular Outcome 2: "Children are connected with and contribute to their world" (p. 29), which adds additional legitimacy to such learning and teaching.

\subsubsection{A United States Case Study}

In a South Carolina public school, twenty-two kindergarten children and their teacher engaged in a year-long collaborative inquiry that investigated how an outdoor learning space could provide a context for understanding webs of connectedness.

At the beginning of the school year, the children expressed interest in revitalizing four raised garden beds which were overgrown with weeds and grass. Appreciating the children's initiative and thoughtfulness, the teacher contacted a group of community members to work alongside the class to prepare the garden area for the autumn planting cycle. The community members who included parents, university academics, and nutritionists offered information about seasonal planting and the benefits of eating locally-grown, organic produce.

The autumn harvest was successful, with the children producing a bounty of kale, lettuces, and Georgia collards. Encouraged by their success, the children then planted a spring garden. A local Elder was enlisted to help the children germinate the seeds. The seedlings were placed in the garden plots that had been replenished from a compost heap containing leaves gathered from a poplar tree. During the spring planting cycle, the children were able to observe many butterflies moving fluidly from the garden area to the poplar tree. Their curiosity led to the educator making contact with a local expert (a naturalist at the University of South Carolina) to further their learning about ecological connections.

This United States case study illustrates the power of incorporating hands-on, real-world, place-based learning experiences within formal school structures and processes (Sobel 2005). Teachers who are responsive to children's interests, and are willing to learn alongside them, can promote both academic achievement as well as an ethic of care for the natural environment. As this case shows, community vitality is also enhanced when community members, children, and their educators purposefully weave webs of connectedness. Further, as in the case from Australia, such learning also helps educators to successfully address learning outcomes in the Head Start Early Learning Outcomes Framework: Ages Birth to Five (Department of Health and Human Services (DHHS) 2015), and in particular, Goal ITATL 6 a "child demonstrates emerging initiative in interactions, experiences, and explorations" (p.14).

The researchers anticipate that these small-scale transnational case studies will provide some initial opportunities for better understanding concepts such as webs of connectedness and the formation of ecological worldviews across multiple ecosystems and multiple socio-cultural contexts. This resonates with Gruenwald's (2008) ideas of bringing together culturallysensitive and place-responsive education that focuses on lived experiences of places. The 
researchers believe there is merit in extending such international perspectives to a wide range of topics to better contribute to global understandings of our shared concerns with sustainability and learning. Higher education institutions have a key role in fostering such research collaborations.

\subsection{A transnational study of ECEfS within early years curriculum frameworks}

Early Childhood Education resounds to a rich cacophony of voices (Moss 2015) and has been recognized as a fertile site for discussion around education for sustainability (EfS). Thus, this (re)search hopes to offer an agnostic inquiry into the visibility of language associated with sustainability within early childhood curricula. Members of this research group sought to locate language and awareness of EfS within the early year's curricula in England, The Early Years Foundation Stage (Department for Education 2014); Australia, Early Years Learning Framework for Australia (DEEWR 2009); the USA, Head Start Early Learning Outcomes Framework: Ages Birth to Five (DHHS 2015); Norway, National Framework Plan for the Content and Tasks of Kindergartens (Ministry of Education and Research 2011); and Sweden, Curriculum for the preschool (National Agency for Education 2010). In order to build on sustainability-related research within early childhood education, these researchers involved in the TND were drawn together to explore early childhood curricula from each of their specific home country perspectives, which will subsequently be used to provoke 'friendly' interrogation of the data.

This (re)search for language associated with ECEfS coexists with the reviewed and newly ratified Sustainable Development Goals (United Nations n.d.) The discourse surrounding EfS will be explored through comparative data analysis of a range of early years' curriculum documentation in international settings, thus contributing to definitions of sustainability as multi-dimensional, rather than acceding to ways of looking at sustainability (and education for sustainability) as singular 'one-size-fits-all' notions regardless of context. Initial scrutiny of the frameworks suggests there may be a lost window of opportunity to explicitly embed the language of EfS in some frameworks. While the research does not claim to be ground breaking, it will seek to remind to practitioners, policy makers and universities that there are many ways of making sense of the world. Paradigms associated with sustainability are often marginalized within teacher education in universities; however early childhood educators have been strong advocates supporting "the foundations of many of their [children's] fundamental attitudes and values" (Siraj-Blatchford, Smith \& Pramling Samuelsson 2008, p. 6). Hence, the purpose of this particular research is to advance the reframing of early childhood curricula so that interrogation of each national curriculum framework may better support and influence thinking about sustainability and EfS more broadly within Higher Education, particularly in teacher education.

The methodology for this sub-program of the TND embraces a collaborative inquiry approach in the hope that international collaboration will "demystify and democratize the process of constructing knowledge" (Bray et al. 2000, p. 19) related to the different curriculum requirements for ECE across international contexts. Explorations, to date, include a comparative analysis of the language about sustainability and EfS embedded in each framework, and has been captured in the form of a comparative table using the three wellarticulated pillars of sustainable development - Cultural Social, Economic, and Environmental (Arlemalm-Hagser \& Davis 2014; Siraj-Blatchford, Smith \& Pramling Samuelsson 2008).

The researchers plan to advance this research focus through working within, and beyond, their sub-groups to network, socialize and collaborate with other experienced, mid and early career 
researchers, with the wider goal of developing an international community of inquiry in Higher Education around ECEfS. The idea of early childhood as a site for philosophic discussion and agentic change is often noted with caution, for example: by Moss (2015), not to see discussion as a magic potion; by Dahlburg and Moss (2005) not to position children as redemptive agents; by Davis and Elliott (2014) who caution against the saviours for sustainability discourse; and by Siraj-Blatchford (2008) not to program children as the ones to solve our present sustainabilty problems. Through this project the researchers aim to reframe early childhood curricula, in order to locate sustainability as occurring within a framework of social practices, and under the gaze of culture and institutions (Foucault 1998). As early childhood education is often positioned by governments as a form of social contract to offer a firm foundation for future education and employment, the relevance of systems thinking (Davis \& Ferreira 2015) also supports the idea of system-wide transformation where the processes of interpretation and construction ultimately transfer to the dialogue with students in higher education who will, in turn it is hoped, become agentic in their work with children and the wider context. These researchers believe there are opportunities to extend such an examination of curriculum policy to the Higher Education sector more broadly. Interrogating curriculum policy offers a wealth of opportunities for discussion around local pedagogic practices as regimes of truth (Foucault 1998). These truths may help us 'do' pedagogies differently, including the identification of multiple ways of working with curricula guidance whilst holding onto advocacy as a key principle.

\subsection{Researching ECEfS in early childhood preservice teacher education}

This research program arising from the TND3 addresses the gap in research about the 'state of play' of sustainability and EfS in early childhood preservice teacher education in international contexts. The general research question being investigated is: 'How is sustainability and EfS/ESD constructed and practised in early childhood preservice teacher education programs?' The study dovetails with the UNESCO Roadmap for Implementing the Global Action Programme on ESD, Priority Action Area 3 'Building capacities of educators and trainers' that emphasizes 'teacher education institutions deliver pre-service and in-service training on ESD’, including early childhood teacher education (UNESCO 2014).

The researchers in this sub-group are from Australia, New Zealand, Sweden, Norway, and Korea although we anticipate that others will join the team as the project expands. Research to date identifies that the inclusion of EfS in teacher education courses has generally been patchy and often the result of committed individuals rather than embedded systemically (Stevenson, Davis, Ferreira, \& Evans 2014). In the case of Australia, this is despite sustainability being identified as a cross-curriculum priority in the national school curriculum (Australian Curriculum Assessment and Reporting Authority [ACARA] 2010) that should be embedded into all learning areas of education for students from Foundation to Year 10. Such increased emphasis on sustainability presents challenges for pre-service teacher education (Effeney \& Davis 2013), and perhaps even more so in early childhood teacher education because of the lack of specialist teacher educators who have an interest in such matters.

This research is at the beginning of a five-phase program expected to stretch over several years.

1. A systemic review on international literature will be conducted. A systemic review helps propose a future research agenda when the way forward is unclear or existing agendas have failed to address an issue (Hemingway \& Brereton 2009). This draws on work in the emerging field of systematic reviews. 
2. Critical policy analysis (Taylor 1997) of university top level strategies, teacher accrediting bodies, curriculum documents, quality indicators for ECE etc. will be conducted to identify potential policy drivers to support a focus on EfS in teacher education programs.

3. An audit of online early childhood teacher education course materials looking for references to sustainability and EfS has commenced.

4. International case studies will be conducted in the 'home' countries of participants to identify enablers and constraints to embedding of EfS within preservice early childhood teacher education programs.

5. The creation of 'communities of practice' $(\mathrm{CoP})$, a broad descriptor characterizing participants coming together - either/both face to face or electronically - to engage with shared topics, issues and challenges (Cox 2005; Wenger, McDermott \& Snyder 2002), will be encouraged.. We see CoPs arising at the level of individual institutions, at the national level of ECE teacher educators, and internationally, where they have the potential to address the increasingly global nature of EfS facilitation by linking people and organizations to local and global sustainability goals.

At the time of writing, the study has commenced in Australia with an audit of online early childhood teacher education course materials being the starting point. Initial findings identify few instances of explicit reference to sustainability or EfS as part of course outlines or offerings. Once the method has been trialled, research participants from partner countries in New Zealand, Sweden, Norway, and Korea will be invited to conduct similar audits in their own countries.

Although this research program is focused on EfS/ESD within early childhood teacher education, it is anticipated that it will offer a model - in full or in part - across a range of faculties and disciplines within a university, with transnational possibilities for connecting researchers, academics and managers with an interest in sustainability and education for sustainability. This is because the project is process-oriented rather than content-focused, aimed at creating the conditions for broad systemic change within universities.

\section{Lessons learned from the TND}

We believe there are a number of practical lessons that can be drawn from considering the growth of the TND and its success in generating new international collaborations in the field of sustainability research. First, is the importance of forming and nurturing personal relationships amongst fellow researchers in your field especially if yours is a small, start-up field of research. The inaugural TND in 2010 brought together ECEfS researchers, most of whom were colleagues, compatriots, or had in some way dialogued - perhaps at a conference, perhaps through online exchanges - with the two academics who organized the initial event. The organizers and early participants drew upon informal networks to invite not only researchers who were currently working on ECEfS projects, but also those whom they knew had expressed interest in the field, without having directly worked in it. These personal connections between researchers have helped to expand both the TND and the field of ECEfS research as participants continue to build and strengthen their international connections through continuing networking and professional collaborations. Building a critical mass is essential! 
It is important to note, however, that while information technologies have allowed participants to maintain good virtual communication with the organizers and each other, faceto-face interactions remain vitally important. This is why the TND remains a physical event, allowing participants to meet, eat meals together, catch trains and planes together, discuss our research in open and supportive ways, and to share our varied multi-national and multidisciplinary perspectives on issues concerning ECEfS. Further, despite the transnational nature of the TND, we have found that access to external funds to support the events has not been necessary as researchers have been willing to either self-fund or have been able to convince their universities to contribute some resources to enable them, individually, to attend. Piggybacking off other major research events, such as international conferences, also enables participants to defray some of their costs.

Additionally, the TND as a network means that all the participants have ownership of the processes and the outcomes. While there are is a small number of key participants who keep the network 'alive', and take some responsibility for sending updates and providing motivation, it is the participants themselves who collaboratively developed the various research agendas and determined what research themes to pursue. This democratic approach has reaped dividends as the list and quality of research outputs demonstrate.

We have found that one of the TND's strengths is that it is outcomes-focused. The emphasis on producing research outcomes such as refereed papers, books and book chapters, and research grant applications, has allowed the TND to maintain momentum between face-toface meetings. Additionally, TND participants have engaged in Visiting Scholar programs between universities, been offered opportunities to present international keynote addresses, served as thesis examiners for national and international TND colleagues, and a myriad other academic tasks that enable individual researchers to build their research careers. Collectively, all these activities have supported the ongoing development of ECEfS as a rich field of research that is reshaping how people see early childhood education and its contribution to sustainability.

\section{Conclusion}

In this paper, we offered the example of the Transnational Dialogues in Early Childhood Education for Sustainability as a means for promoting collaborative research and reorienting the tertiary education sector towards sustainability, with particular reference to the the field of early childhood education. Ongoing research dialogues have sustained this informal decentralized network of early childhood education for sustainability researchers that originated in the first international meeting of participants in 2010. These dialogues have allowed a growing band of sustainability-focused researchers, from an expanding list of countries, to network and collaborate with like-minded colleagues. This international community of practice has served as the stimulus for a range of outputs that reflect the positive interactions that can result from bringing together multi-national and multidisciplinary perspectives and experiences. Some practical implications have included education for sustainability becoming a research theme in the University of Stavanger's annual $\mathrm{PhD}$ program in early childhood education in Norway. Meanwhile in England there has been a recent revalidation of an early childhood related degree in England where the programme is grounded in both local and global early childhood realities and framed with clear reference to both UN and UK policy and programmes.

Finally, we have written this paper in the same spirit as the TND itself - it is a collaboration across countries and contexts, bringing together researchers at various levels of experience 
and expertise to encourage the promulgation of new fields of sustainability research. It is hoped that the dialogic processes of the TND may offer a productive model for other groups and sectors to draw upon in embedding sustainability into their higher education environments.

\section{References}

Arlemalm-Hagser, E. \& Davis, J. 2014, 'Examining the rhetoric: a comparison of how sustainability and young children's participation and agency are framed in Australian and Swedish early childhood education curricula', Contemporary Issues in Early Childhood, vol. 15, no. 3, pp. 231-244.

Australian Curriculum, Assessment and Reporting Authority. 2010, Cross-curriculum priorities: Sustainability, Sydney, viewed 26 March 2016, <http://www.australiancurriculum.edu.au/CrossCurriculumPriorities/Sustainability>.

Bray. J., Lee, J., Smith, L. \& Yorks, L. 2000, Collaborative inquiry in practice: Action, reflection and making meaning, Sage, London.

Cox, A. 2005, 'What are communities of practice? A comparative review of four seminal works', Journal of Information Science, vol. 1, no. 6, pp. 527-540.

Dahlberg, G. \& Moss, P. 2005, Ethics and politics in early childhood education, Routledge Falmer, London.

Davis, J. 2009, 'Revealing the research 'hole' of early childhood education for sustainability: A preliminary survey of the literature', Environmental Education Research, vol. 15, no. 2, pp. 227-241.

Davis, J. \& Elliott, S. (eds). 2014, Research in early childhood education for sustainability: International perspectives and provocations, Routledge, London.

Davis, J. \& Elliott, S. (eds) 2015, Research in early childhood for sustainability: International perspectives and provocations, Trans. O. Ji, M. Huh \& E. Baik, Changjisa, Seoul.

Davis, J. \& Ferreira, J. 2015, 'Using research and a systems approach to mainstream change in early childhood education for sustainability', in J. Davis (ed.), Young children and the environment: Early education for sustainability, Cambridge University Press, Port Melbourne, pp. 320-355.

Department for Education. 2014, Statutory framework for the early years foundation stage. London.

Department of Education Employment and Workplace Relations. 2009, Belonging, being and becoming: The early years learning framework for Australia, Commonwealth of Australia, Canberra.

Department of Health and Human Services. 2015, Head start early learning outcomes framework, Washington. Retrieved from

http://eclkc.ohs.acf.hhs.gov/hslc/hs/sr/approach/pdf/ohs-framework.pdf

Effeney, G. \& Davis, J. 2013, 'Education for sustainability: a case study of preservice primary teachers' knowledge and efficacy', Australian Journal of Teacher Education, vol. 38, no. 5, pp. 32-46.

Foucault, M. 1998, The Will to knowledge, Penguin, London.

Gruenwald, D. 2008, 'The best of both worlds: A critical pedagogy of place', Environmental Education Research, vol. 14, no. 3, pp. 308-324. 
Hemingway, P. \& Brereton, N. 2009, What is a Systematic Review? 2nd edn, Hayward Medical Communications. What is...? series. [online]. Retrieved from http://www.medicine.ox.ac.uk/bandolier/painres/download/whatis/Syst-review.pdf

Inoue, M. 2014, 'Perspectives on early childhood environmental education in Japan: Rethinking for a sustainable society', in J. Davis \& S. Elliott (eds), Research in early childhood for sustainability: International perspectives and provocations, Routledge, London, pp. 87- 95.

Moss, P. 2015, 'There are alternatives! Contestation and hope in early childhood Education', Global Studies of Childhood, vol. 5, no. 3, pp. 226 -238.

National Agency for Education. 2010, Curriculum for the preschool. Stockholm.

Siraj-Blatchford, J. 2008, 'The implications of early understandings of inequality, science and technology for the development of sustainable societies', in I. Pramling Samuelsson \& Y. Kaga (eds), The Contribution of early childhood education to a sustainable society, UNESCO, Paris, pp. 67- 72.

Siraj-Blatchford, J., Smith, K. \& Pramling Samuelsson, I. 2008, Education for Sustainable Development. Organisation Mondiale Pour l'Education Prescolaire (OMEP), Retrieved from http://www.327matters.org/Docs/ESD\%20Book\%20Master.pdf

Sobel, D. 2005, Place-based education: Connecting classrooms and communities. The Orion Society, Massachusetts.

Stevenson, B., Davis, J., Ferreira, J. \& Evans, N. 2014, A state-wide systems approach to embedding the learning and teaching of sustainability in teacher education. Office of Learning and Teaching, Australian Government Department of Education, Canberra.

Taylor, S. 1997, 'Critical Policy Analysis: exploring contexts, texts and consequence', Discourse: studies in the cultural politics of education, vol. 18, no. 1, pp. 23-34.

United Nations Educational, Scientific and Cultural Organization [UNESCO]. 2005, UN Decade of Education for Sustainable Development, Paris.

United Nations Educational, Scientific and Cultural Organization. 2014, Roadmap for Implementing the Global Action Programme on Education for Sustainable Development, Paris. Retrieved from http://unesdoc.unesco.org/images/0023/002305/230514e.pdf

United Nations. n.d., Sustainable development goals. Retrieved from https://sustainabledevelopment.un.org/sdgs

Wenger, E., McDermott, R. \& Snyder, W. 2002, Cultivating communities of practice: Guide to managing knowledge, Harvard Business School Press, Cambridge, USA.

\section{Author Biographies:}

Sherridan Emery is a PhD candidate in the Faculty of Education at the University of Tasmania and Programs Coordinator for Awards and Grants in the Tasmanian Institute of Learning and Teaching based within the university. Her PhD project explores teachers' perspectives of cultural wellbeing in classroom communities. Sherridan is an active researcher across numerous school and community-based research collaborations at the University of Tasmania focusing on the intersections between wellbeing, the arts and sustainability. 
Professor Julie M. Davis is based in the School of Early Childhood at Queensland University of Technology. Her special areas of interest are early childhood education for sustainability and embedding sustainability into teacher education. She is the editor of the internationally-successful text book for preservice early childhood teacher education, "Young Children and the Environment: Early Education for Sustainability" (Cambridge 2010; 2015), and co-editor of the research text 'Research in Early childhood Education for Sustainability: International Perspectives and Provocations' (Routledge, 2014). She has co-authored a number of reports, chapters and papers on a 10 year project on teacher education and sustainability in Australia.

Associate Professor Barbara Maria Sageidet researches and teaches at the Institute of Early Childhood Education, University of Stavanger, Norway. Her background and $\mathrm{PhD}$ was related to botany, ecology, paleoecology and soil sciences. Since 2007 she has worked in the field of early childhood education with a research focus on sustainability, science education, and inquiry learning in the kindergarten.

Nicky Hirst is the Programme leader for the undergraduate BAH Early Childhood Studies degree at Liverpool John Moores University. She worked in the early years sector for over fifteen years before moving into higher education where she has taught extensively within early childhood degree programs and mentoring students on pathways for Early Years Professional Status. Nicky is a member of the Early Childhood Studies degree forum, Early Education and OMEP. Her qualifications include an Early Childhood Studies BA Hons from Manchester Metropolitan University and a Masters degree in Academic Practice in Higher Education. Nicky is currently working towards $\mathrm{PhD}$ by publication.

Diane Boyd is a senior lecturer at Liverpool John Moores University in the department of education teaching across Early Childhood studies, Education Studies and Early Years. Her qualifications include a B.Ed. (Honours) in Primary Education and drama, an M.A. in Early Years Education, and Certificates of Advanced Studies in Early Years and in Mentoring. Diane was a classroom teacher in Early Years for nearly twenty years and has co- authored a book Understanding Early Years across the UK: Comparing practice in England, Northern Ireland, Scotland and Wales. She is leading a task force in England on embedding sustainable practice into the early years nationally with Eco schools England and OMEP UK and is currently working on her PHD by publication.

Jamison K. Browder is a doctoral candidate at the University of South Carolina. He is also a full-time early childhood practitioner working with children aged four to six years old. His research interests include outdoor play, early childhood education for sustainability in public school settings and forest kindergartens. Most importantly, Mr. Browder and his wife, Jennifer, are the proud parents of three wonderful children: Will, Miles and Townsend. 